\title{
PRELIMINARY RESULTS OF NATURAL ATTENUATION MODELING IN THE WEST BRANCH CANAL CREEK AREA, ABERDEEN PROVING GROUND, MARYLAND
}

By Jonathan C. Johnson

U.S. GEOLOGICAL SURVEY

Open-File Report 00-287

In cooperation with the

U.S. ARMY GARRISON, ABERDEEN PROVING GROUND

ENVIRONMENTAL CONSERVATION AND RESTORATION DIVISION

ABERDEEN PROVING GROUND, MARYLAND

The contents of this report have been approved for public release and unlimited distribution by the U.S. Army -clearance number 3242-A-4.

Baltimore, Maryland

2000 


\section{U.S. DEPARTMENT OF THE INTERIOR \\ BRUCE BABBIT, Secretary}

\section{U.S. GEOLOGICAL SURVEY}

Charles G. Groat, Director

The use of trade, product, or firm names in this report is for descriptive purposes only and does not imply endorsement by the U.S. Government.

For additional information write to:

District Chief

U.S Geological Survey 8987 Yellow Brick Road

Baltimore, MD 21237
Copies of this report can be purchased from:

U.S. Geological Survey

Branch of Information Services

Box 25286

Denver, CO 80225-0286 

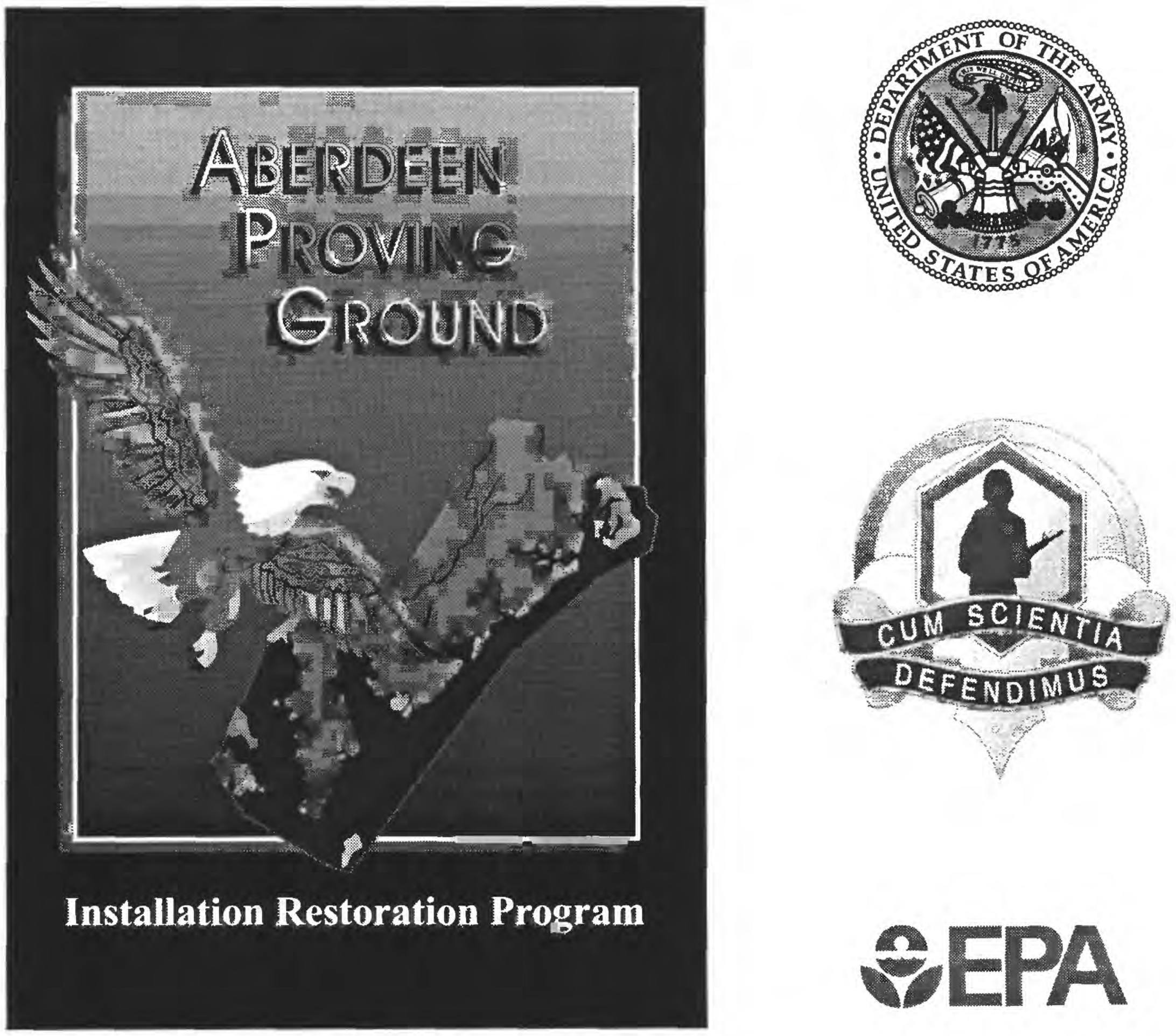

\section{₹USGS \\ science for a changing world}

2000

Aberdeen Proving Ground, Edgewood Area 


\section{CONTENTS}

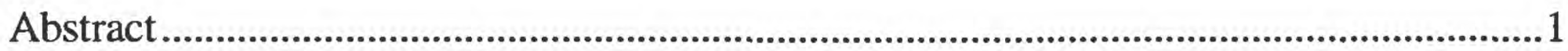

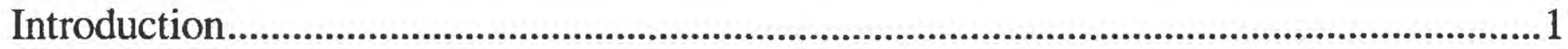

Hydrogeology and contaminant distribution ......................................................................

Numerical model and simplifying assumptions...............................................................

Model domain and discretization.......................................................................9

Hydrologic boundary conditions ...........................................................................

Simplifying assumptions for the model ...................................................................11

Hydrogeology of the study area...................................................................11

Contaminant distribution .............................................................................11

Microbiology ....................................................................................... 14

Biodegradation reaction pathways.............................................................. 14

Model calibration, sensitivity analysis, and results .........................................................19

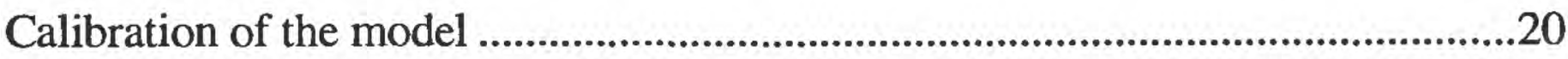

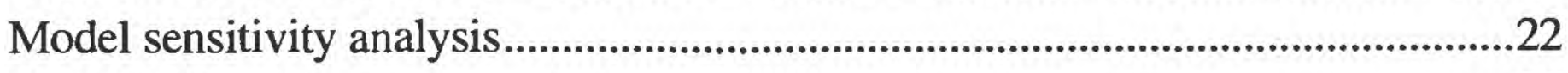

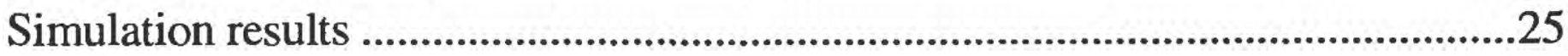

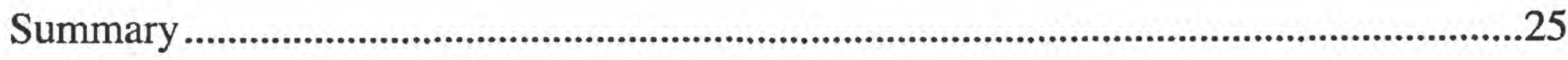

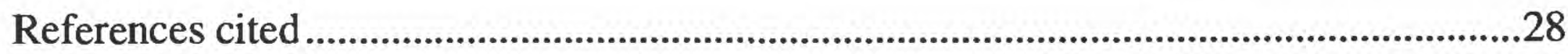




\section{FIGURES}

1. - 3. Maps showing:

1. Location of Canal Creek area and West Branch study area, Aberdeen Proving Ground, Maryland

2. Location of the wetland study area along the West Branch Canal Creek, and the distribution of total organic halogen in the Canal Creek aquifer upgradient from the wetland. 3

3. Locations of sampling sites and sections $A-A^{\prime}$ and $C-C^{\prime}$ in the wetland study area along the West Branch Canal Creek

4. Generalized hydrogeologic section showing directions of ground-water flow in the Canal Creek area.

5. Simulation domain, hydrologic boundary conditions, and relevant hydrogeologic features for the calibrated model at West Branch Canal Creek .

6. Measured concentrations of 1,1,2,2-tetrachloroethane (PCA) in well CC27A in the West Branch Canal Creek area

7. Distribution of redox zones in the calibrated model at the West Branch Canal Creek

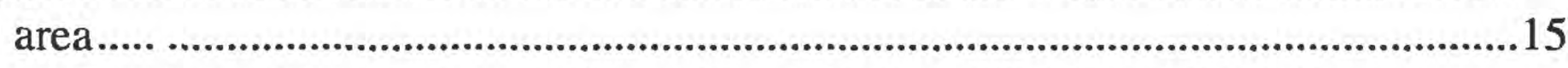

8. Anaerobic degradation pathways for trichloroethylene (TCE) and 1,1,2,2tetrachloroethane (PCA) .................................................................................

9. Simplified reaction pathways used in the calibrated model ….....................................17

10. Microcosm data and best-fit sequential first-order decay model...................................18

11. Sensitivity of the model to parameter values as measured by changes in ground-water levels..

12. Sensitivity of the model to parameter values as measured by changes in $1,1,2,2-$ tetrachloroethane (PCA) concentrations

13. Calculated steady-state concentrations of chlorinated volatile organic compounds for the calibrated model at West Branch Canal Creek .26

\section{TABLES}

1. Model-calibration data for two-dimensional ground-water-flow and solute-transport model at West Branch Canal Creek, Aberdeen Proving Ground, Maryland . 
CONVERSION FACTORS, ABBREVIATIONS, AND VERTICAL DATUM

\begin{tabular}{rcl}
\hline Multiply & By & To obtain \\
\hline inch (in.) & 2.54 & centimeter \\
inch (in.) & 25,400 & micrometer \\
inch per year (in/yr) & 0.02540 & meter per year \\
foot (ft) & 0.3048 & meter \\
foot per day (ft/d) & 0.3048 & meter per day \\
foot per year (ft/yr) & 0.3048 & meter per year \\
foot squared per day (ft $\left.{ }^{2} / \mathrm{d}\right)$ & 0.09290 & meter squared per day \\
mile (mi) & 1.609 & kilometer \\
\hline
\end{tabular}

Vertical Datum: In this report, "sea level" refers to the National Geodetic Vertical Datum of 1929-a geodetic datum derived from a general adjustment of the first-order level nets of the United States and Canada, formerly called Sea Level Datum of 1929.

Other abbreviated units of measure: Water temperature, chemical concentration, and other chemical and physical properties of constituents are given in metric units. Water temperature in degrees Celsius $\left({ }^{\circ} \mathrm{C}\right)$ can be converted to degrees Fahrenheit $\left({ }^{\circ} \mathrm{F}\right)$ by use of the following equation:

$$
{ }^{\circ} \mathrm{F}=1.8\left({ }^{\circ} \mathrm{C}\right)+32
$$

Chemical concentration in water is expressed in milligrams per liter $(\mathrm{mg} / \mathrm{L})$ or micrograms per liter $(\mu \mathrm{g} / \mathrm{L})$.

Molecular weight and other mass expressions are expressed in grams (g), density is given in grams per cubic centimeter $\left(\mathrm{g} / \mathrm{cm}^{3}\right)$. Other abbreviations include milliliter $(\mathrm{mL})$ or liter $(\mathrm{L})$ for volume measurements. 


\title{
PRELIMINARY RESULTS OF NATURAL ATTENUATION MODELING IN THE WEST BRANCH CANAL CREEK AREA, ABERDEEN PROVING GROUND, MARYLAND
}

\author{
by Jonathan C. Johnson
}

\begin{abstract}
In cooperation with the U.S. Army, the U.S. Geological Survey is investigating the processes of natural attenuation at West Branch Canal Creek, Aberdeen Proving Ground, Maryland. Natural attenuation refers to the naturally occurring processes that serve to reduce mass, or concentration of a contaminant in the environment. Biodegradation, dispersion, and abiotic transformation are possible mechanisms for the reduction of contaminant mass, or concentration in ground water.

West Branch Canal Creek is a tidally influenced freshwater wetland that receives discharge from a sand aquifer beneath the wetland. A plume of chlorinated volatile organic compounds in the aquifer is transported to the wetland sediments where it undergoes biodegradation. Previous U.S. Geological Survey studies described the hydrogeology, geochemistry, and biogeochemistry of this site. This information has been used to simulate the processes of natural attenuation.

Simulations based on data from a limited part of the wetland show that 99.89 percent of the parent compound 1,1,2,2-tetrachloroethane is removed from the subsurface by biodegradation processes. Simulating the natural attenuation processes required the use of simplifying assumptions regarding the hydrology and transport properties of the materials at the site. The most important simplifying assumptions relevant to the results are as follows: (1) the diurnal and seasonal changes in ground-water levels due to the influence of the tides are not included; (2) the ground-water flow and reactive-solute transport are represented using a two-dimensional steady-state simulation; and (3) a simplified set of biodegradation reactions is employed rather than the whole set of reactions and resultant daughter products. The model is sensitive to dispersivity and velocity, and would benefit from additional data on these parameters.
\end{abstract}

\section{INTRODUCTION}

Aberdeen Proving Ground, which is a U.S. Army base in northern Maryland (fig. 1), has been the primary chemical-warfare research and development center for the United States since 1917. Most of the chemical manufacturing and munitions filling plants were located in the Canal Creek area. Many of the plants were abandoned or demolished after World War II.

A plume of contaminated ground water at the base (fig. 2) is discharging from the sand aquifer beneath the wetland to the wetlands of West Branch Canal Creek. In cooperation with the U.S. Army, the U.S. Geological Survey (USGS) has been evaluating the process of natural attenuation of the plume of chlorinated volatile organic compounds (CVOCs). The role of the USGS has included defining the hydrogeology, sampling the ground water for CVOCs, describing the biogeochemistry, and evaluating the capability of the system to biodegrade the CVOCs. The goal of prior USGS work at the site was to provide a framework for understanding the distribution and movement of the CVOCs, and to 


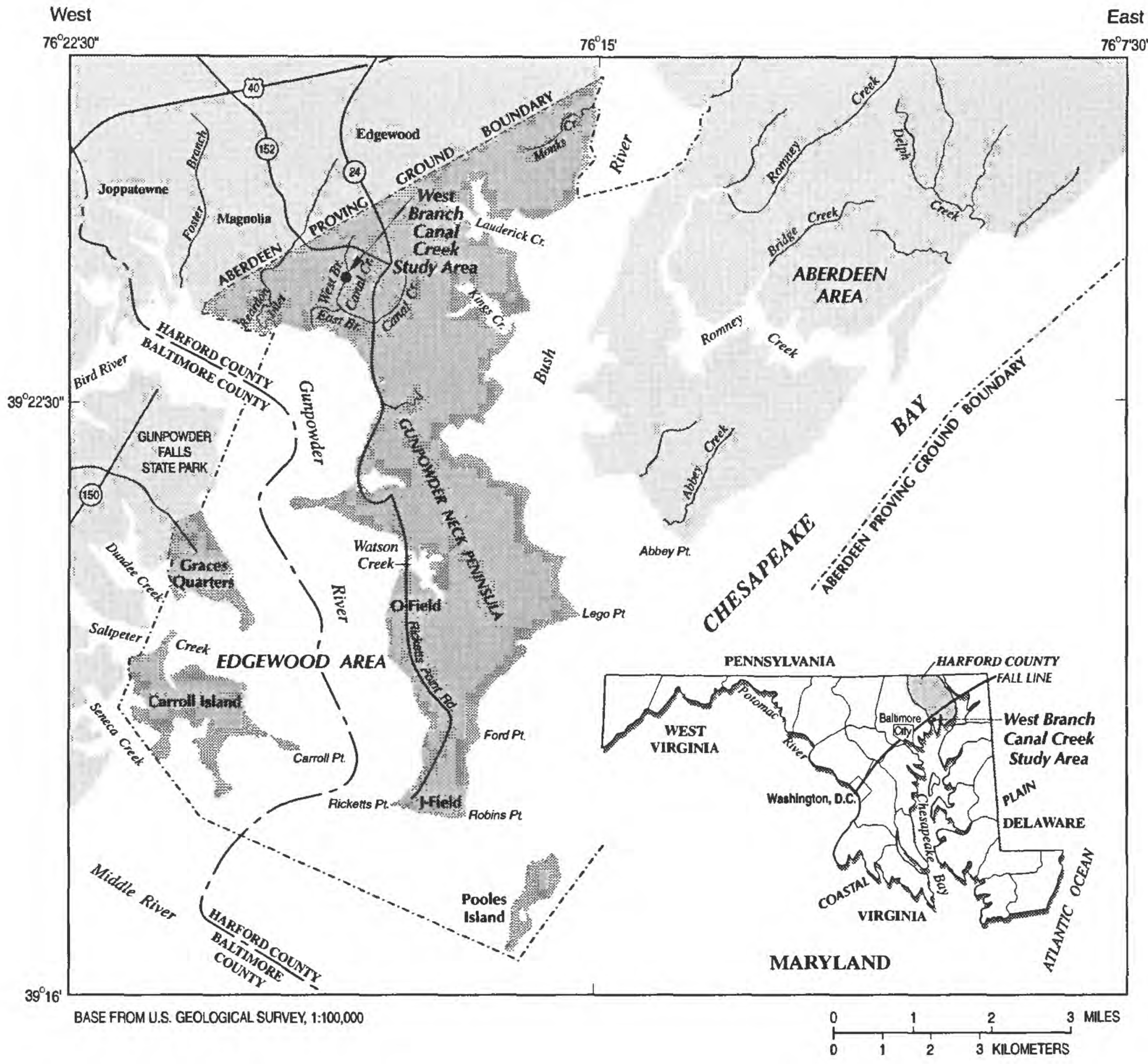

Figure 1. Location of Canal Creek area and West Branch study area, Aberdeen Proving Ground, Maryland (modified from Lorah and others, 1997, fig. 1). 


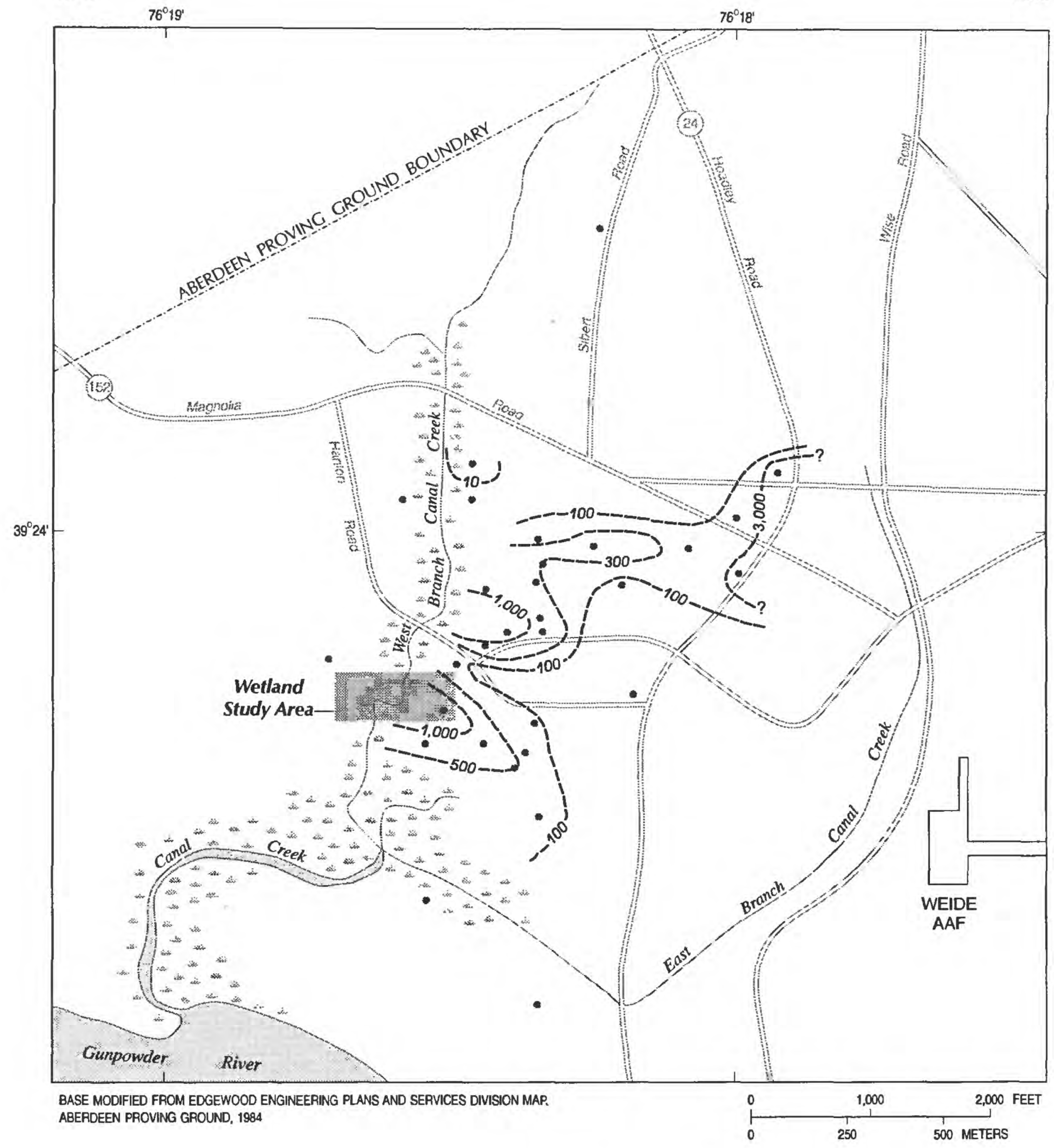

EXPLANATION

?--10-- APPROXIMATE LINE OF EQUAL TOTAL ORGANIC HALOGEN CONCENTRATION -- Interval, in micrograms per liter, is variable. Queried where uncertain. Sampled in July-September 1988.

- WELL SITE

Figure 2. Location of the wetland study area along the West Branch Canal Creek, Aberdeen Proving Ground, Maryland, and the distribution of total organic halogen in the Canal Creek aquifer upgradient from the wetland (from Lorah and others, 1997, fig.2). 
quantify the extent of natural attenuation. The objectives of this report are to begin to quantify the effect of biodegradation on the fate of the CVOCs, and to begin to examine the sensitivity of the system to changes in environmental conditions.

This report presents preliminary results of simulations of natural attenuation of CVOCs along a transect (C-C' in figure 3 ) perpendicular to and extending about 200 feet southeasterly from the creek. The results presented here, which are based on two-dimensional ground-water-flow and contaminant-transport modeling conducted by the USGS during Federal fiscal years 1998 and 1999, are considered preliminary in that the simulated distribution of CVOC daughter products has not been calibrated to actual data. The long-term modeling objectives are to quantify the natural attenuation processes at West Branch Canal Creek, and to examine the sensitivity of the system to changes in environmental conditions.

The hydrogeology of the Canal Creek area is described in Oliveros and Vroblesky (1989), and the ground-water chemistry and the distribution of organic and inorganic contaminants in the area are described in Lorah and Vroblesky (1989). These reports delineated the extent of the contamination in the Canal Creek area and helped to guide subsequent investigations. Historical industrial production data were combined with measured concentration distributions and hydrogeologic information to divide the Canal Creek area into subregions of similar character (Lorah and Clark, 1996). This division into subregions helped focus subsequent studies into well-defined units. Results of the investigation of the CVOC contamination along West Branch Canal Creek are presented in consultant reports (such as Jacobs Engineering Group Inc., 1995), and two USGS publications -- a report describing the data and data-collection methods (Olsen and others, 1997), and a report describing analysis of the data and the transformation of the contaminants by natural attenuation processes (Lorah and others, 1997). This report builds on the analysis completed by Lorah and others (1997), using the conceptual model developed therein, hydraulic heads, contaminant distribution, and distribution of microbiological indicators, to construct numerical simulations of the fate and transport of the contaminants along West Branch Canal Creek.

\section{HYDROGEOLOGY AND CONTAMINANT DISTRIBUTION}

West Branch Canal Creek is a tidally influenced freshwater wetland. The discharge to the wetland is primarily from local ground-water-flow systems recharged by infiltration. The wetland sediments are organic-rich silts and clays that are 7 to 12 feet $(\mathrm{ft})$ thick. The wetland sediments are comprised of an upper peat unit and a lower clayey unit. The upper unit has a higher organic content and slightly different mineralogy than the lower unit (Lorah and others, 1997). Approximately 40 to $45 \mathrm{ft}$ of sand and gravel of the Canal Creek aquifer underlie the wetland sediments. This aquifer becomes thinner on the west side of West Branch Canal Creek. Thin, discontinuous clay lenses are common in the Canal Creek aquifer. Beneath this aquifer is a 60 -ft-thick clay confining unit, known as the lower confining unit. 


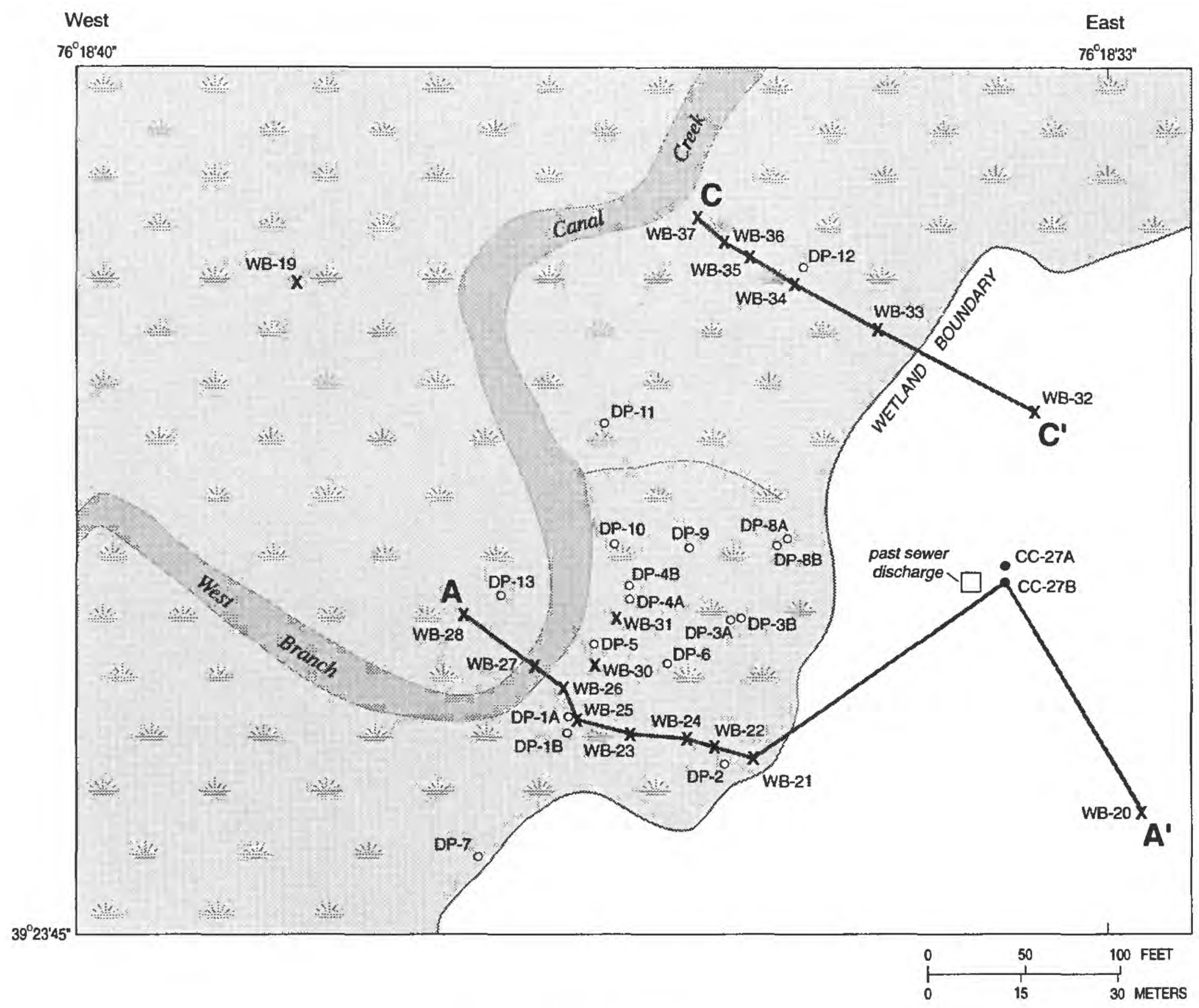

EXPLANATION

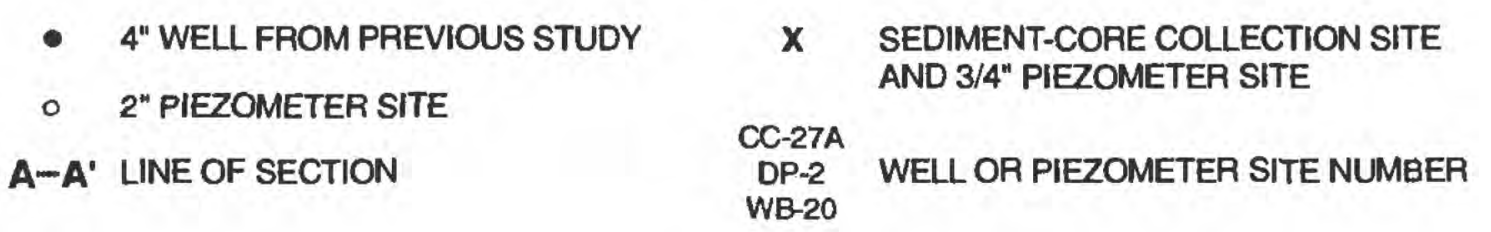

Figure 3. Locations of sampling sites and sections $A-A^{\prime}$ and $C-C^{\prime}$ in the wetland study area along the West Branch Canal Creek (modified from Lorah and others, 1997, fig. 3). 

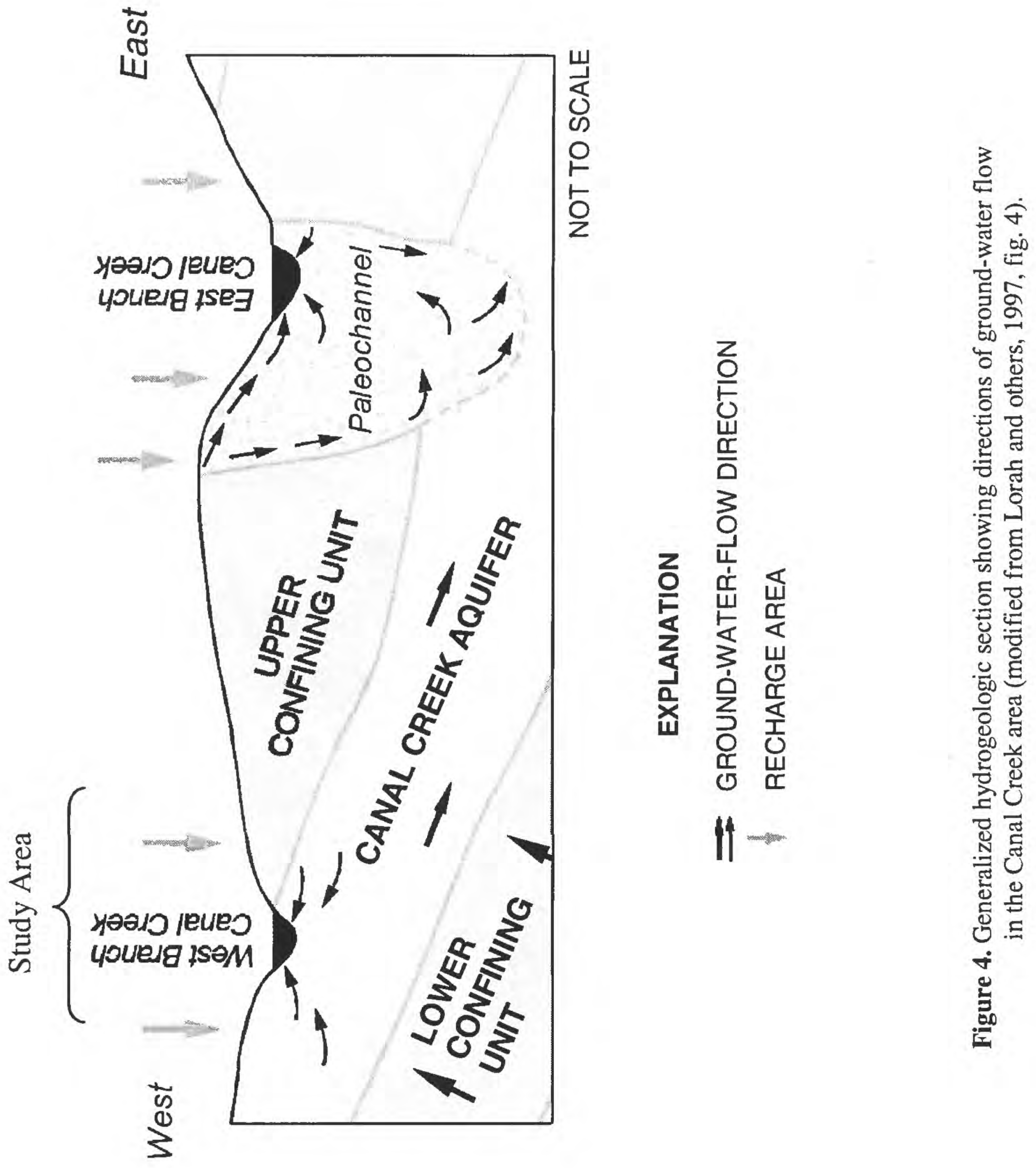
The uplands surrounding the creek have been the site for military-industrial activities since World War I. The surface materials are composed of redistributed native materials and fill materials. The native surface materials consist of an upper confining unit (silts and clays) that is replaced by surficial aquifer materials in some places. The surface is paved in many locations, and the top layer over much of the area nearest the creek is composed of heterogeneous fill materials. In regions where the surficial aquifer is present, space between paved areas allows infiltrating water to recharge the local ground-waterflow system. Depth to water ranges from about $5 \mathrm{ft}$ to $20 \mathrm{ft}$ below land surface in the upland areas. A generalized hydrogeologic section showing directions of ground-water flow is shown in figure 4.

Measurements of hydraulic head, contaminant distribution, and microbiological indicators are reported in Lorah and others (1997) and Olsen and others (1997). Those investigations focused on CVOC distribution and indicators of microbiological activity. The data were gathered primarily along two transects, one north and one south of well CC27A, near the location of the former sewer discharge along West Branch Canal Creek (fig. 3). Each transect runs roughly perpendicular to the creek from the upland area beside the wetland, across the eastern part of the wetland to the creek. The southern transect continues across the creek. Each transect traverses roughly $200 \mathrm{ft}$ of wetland and contains at least five well clusters.

Synoptic measurements of hydraulic head were made periodically along these transects from March 1995 to July 1999. Continuous measurements of hydraulic head were made at several locations to investigate tidal influence on the Canal Creek aquifer, and to define hydraulic parameters for the Canal Creek aquifer and the wetland sediments.

Hydraulic conductivities were estimated by use of slug tests and analysis of the effects of tides in both the Canal Creek aquifer and in the wetland sediments. The estimated hydraulic conductivity in the Canal Creek aquifer ranges from 10 to 0.01 feet per day (ft/d) (Lorah and others, 1997). The estimated hydraulic conductivity of the wetland sediments ranges from 0.4 to $0.0003 \mathrm{ft} / \mathrm{d}$ (Lorah and others, 1997).

Sorption of CVOCs to the Canal Creek aquifer sediments is expected to be minimal due to the lack of organic carbon in the sediment [median fraction organic carbon, 0.000026, based on 32 samples (Lorah and Vroblesky, 1989)]. In the wetland sediments, however, the organic-carbon content is quite high, averaging 18 percent in the upper peat unit, and the expected retardation coefficient for the CVOCs of interest is between 6 and 10 (Lorah and others, 1997). The retardation coefficient for the aquifer sediment is assumed to be 1 for this study.

Comprehensive measurement of the spatial distribution of ground-water contaminants and microbiological indicators was conducted once between June and October 1995 (Olsen and others, 1997). Interpretation of the contaminant distribution along the transects in two-dimensional profile is presented in Lorah and others (1997). Indicators of microbiological activity allow the transects to be divided into regions where dominant oxidationreduction (redox) processes take place (Lorah and others, 1997). Distribution of redox processes in the subsurface is important because redox conditions affect microbial transformation of CVOCs.

Chlorinated organic contaminants at the site include trichloroethylene (TCE); 1,1,2,2- tetrachloroethane (PCA); 1,1,2- trichloroethane (112TCA); chloroform; carbon tetrachloride; cis-1,2- dichloroethylene (cis-DCE); trans-1,2- dichloroethylene (transDCE); 1,2- dichloroethane (12DCA); and vinyl chloride (VC). The original contaminants 
are presumed to be PCA, TCE, chloroform, and carbon tetrachloride. Most other CVOCs observed at the site are presumed to be the product of biodegradation processes acting on these compounds. The primary CVOCs of concern are PCA and TCE, because their concentrations are higher than the concentrations of the other CVOCs at West Branch Canal Creek. PCA was present at the highest concentration of any CVOC at the site, especially along the northern transect. The highest measured concentration of CVOCs in the vicinity of the northern transect was in well CC27A, which is near a former sewer-line discharge point that may have contributed to the CVOC contamination. The degradation products of PCA and TCE are discussed in more detail in Lorah and others (1997).

The first-order biodegradation rate for PCA under methanogenic conditions was about 0.25 per day, as measured by anaerobic microcosm studies (Lorah and others, 1997). A similar rate was found for TCE under methanogenic conditions.

\section{NUMERICAL MODEL AND SIMPLIFYING ASSUMPTIONS}

At West Branch Canal Creek, several major processes contribute to the natural attenuation of CVOCs in ground water. Among the most important are biodegradation, dispersion in ground water, and sorption of the CVOCs to soil sediment. No numerical model currently exists that is ideally suited to quantifying all of the natural attenuation processes at West Branch Canal Creek; however, the USGS model BIOMOC (Essaid and Bekins, 1997) can be helpful in quantifying some of them.

BIOMOC is a multispecies solute-transport model that provides for simulation of biodegradation. It can simulate ground-water flow and solute transport in two dimensions and is capable of simulating complex reaction pathways. The transport solution is based on the USGS Method of Characteristics model, MOC (Konikow and Bredehoeft, 1978). BIOMOC, however, has limitations in its application to the study area. The flow package in the model does not allow for simulation of tides. Although the model allows for distributed parameters (properties that vary with location) such as hydraulic conductivity, initial concentration of contaminants, and biologic populations, it is not capable of simulating distributed retardation coefficients. The results of simulations made with this model must be interpreted with these limitations in mind.

The specific equations solved and the solution algorithm used are presented in the BIOMOC documentation report (Essaid and Bekins, 1997). Specific simplifications to the equations used in this study are as follows: (1) the flow equation is solved as a steady-state equation; (2) the transport simulations are run until the solutes have reached steady state; however, the Method of Characteristics transport algorithm requires that the equation be solved as a transient equation; (3) the multiple Monod formulation of the biodegradation equations is used, and competitive inhibition factors are used to limit biodegradation reactions to specific spatial locations (to keep biodegradation in the anaerobic zone only); (4) biologic populations are assumed to be at steady state; and (5) first-order decay is simulated using the method described in the documentation report (Essaid and Bekins, 1997), rather than the full Monod kinetics formulation. 


\section{Model Domain and Discretization}

The area simulated by the model is a two-dimensional slice along transect C-C' (fig. 3). The model boundary is about $30 \mathrm{ft}$ east of well WB33 and extends beyond the creek channel. The simulation domain, the relevant hydrogeologic features, and the boundary conditions for flow are shown in figure 5. To adequately represent the complex reactions occurring within the wetland sediments, the model required a fine discretization. BIOMOC uses a uniform grid spacing for each spatial dimension. Grid blocks in these simulations are $4.9 \mathrm{ft}$ long (horizontally) by $1.3 \mathrm{ft}$ high (vertically), with a domain 68 blocks long and 60 blocks high. BIOMOC simulates the domain as a two-dimensional system but allows a thickness for each block. For the simulations presented here, the domain is assumed to be $3.3 \mathrm{ft}$ thick. Using a two-dimensional model requires the simplifying assumption that the model can adequately represent the ground-water flow and transport in only two spatial dimensions.

The steady-state ground-water-flow equation is solved to obtain velocities for the solute-transport algorithm, which is used in this case to simulate steady-state solute conditions. This is accomplished by running the transport simulations until the concentration at each of the calibration locations is no longer changing with time. The transport algorithm uses the Method of Characteristics to solve the transport equations for solutes in ground water. The maximum time step is set by specifying the maximum distance (measured in number of grid blocks) a particle may travel in one time step. The maximum distance allowed in these simulations is one-half the size of a grid block.

\section{Hydrologic Boundary Conditions}

Hydrologic boundary conditions for the simulations (fig. 5) were selected on the basis of measured ground-water levels and the ability of a boundary condition to adequately represent the calibration data. The eastern boundary of the domain is represented by a constant-head boundary of $5.0 \mathrm{ft}$. A no-flow boundary was selected for the western boundary of the simulation because the wetland is conceptualized as a discharge zone that is the same east of the creek as it is west of the creek. This conceptualization results in a model that assumes the ground-water-flow system is symmetric about the western model boundary. The lack of ground-water-level data in the wetland for the western side of the creek makes selection of this boundary condition and its location somewhat arbitrary.

The bottom of the domain is divided into two sections. The western part of the bottom boundary is represented by a no-flow boundary because of the presence of the lower confining unit. The eastern part of the lower boundary is represented by a constant-head boundary identical to the magnitude at the eastern boundary $(5.0 \mathrm{ft}$ in the calibrated simulation). This boundary condition was selected on the basis of its ability to represent the observed hydraulic heads in the lower part of the domain. 


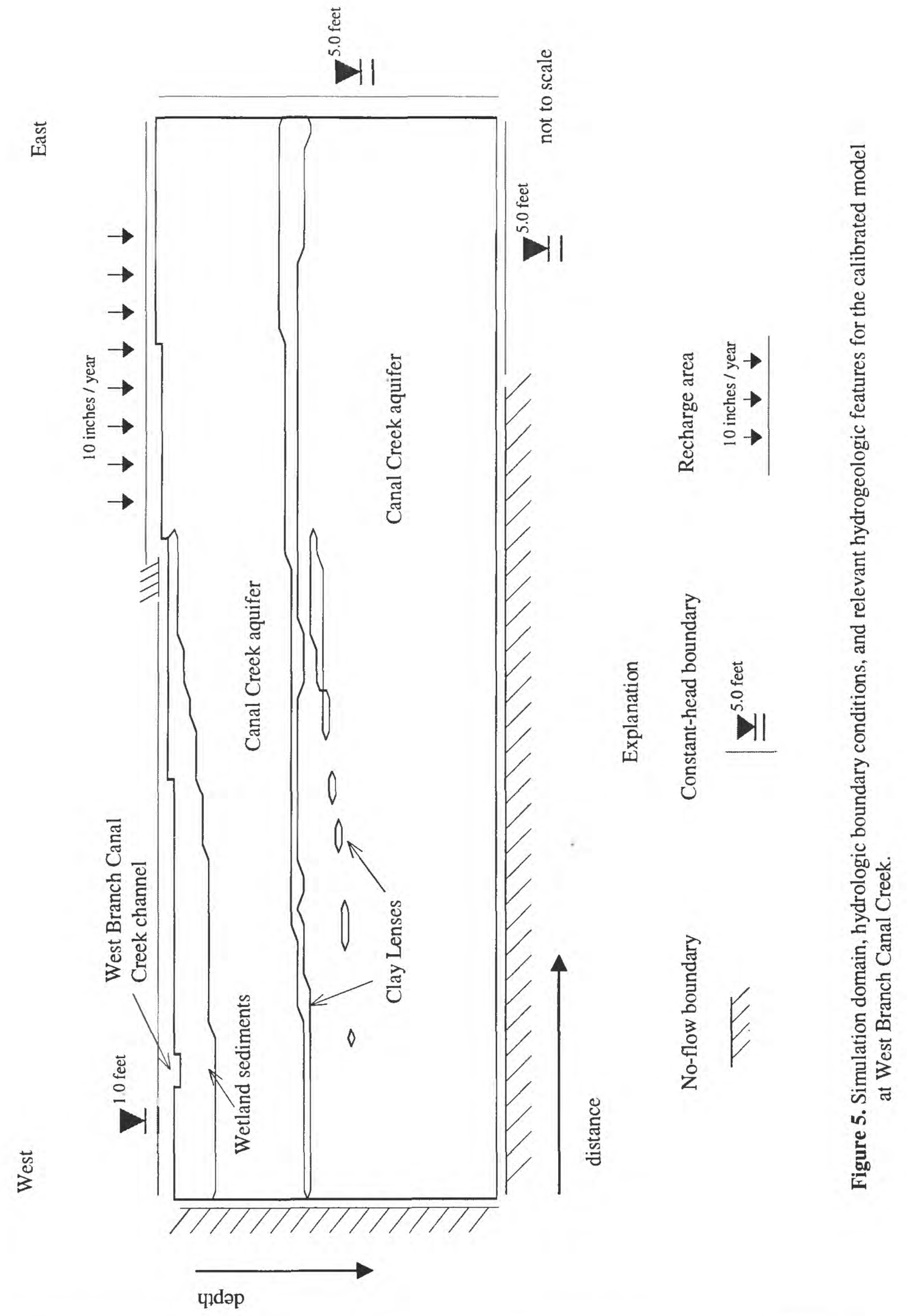

Preliminary Results of Natural Attenuation Modeling, APG, Maryland 
The top of the domain is divided into three sections. The western part of the domain, which is regularly inundated by the tides, is modeled as a constant-head boundary of $1.0 \mathrm{ft}$ (approximate mean value for the tide at this location). The central part of the domain is simulated as a no-flow boundary. This region is assumed to act as a recharge zone some of the time and as a discharge area at other times. The average condition for this region is assumed to be neither recharge nor discharge. The eastern part of the domain is simulated as a recharge area, with a value of 10 inches (in.) of recharge per year. This number was selected on the basis of a reduced value from the calibrated flow model of Lorah and Clark (1996), which used a recharge rate of 13.5 inches per year (in/yr) for the upland regions of the Canal Creek area. This value was decreased to $10 \mathrm{in} / \mathrm{yr}$ because it was assumed that the near-stream sediments of this region are likely to reach saturation with less recharge (thereby becoming discharge areas) than the average sediments of the upland areas.

\section{Simplifying Assumptions for the Model}

Several important simplifying assumptions are made in these simulations. The major assumptions are organized into four categories that are discussed below: hydrogeology, contaminant distribution, microbiology, and biodegradation reaction pathways. The most important simplifying assumptions relevant to the results are as follows: (1) the diurnal and seasonal changes in ground-water levels due to the influence of the tides are not included; (2) ground-water flow and reactive-solute transport are represented using a twodimensional steady-state simulation; and (3) a simplified set of biodegradation reactions is employed rather than the whole set of reactions and resultant daughter products.

\section{Hydrogeology of the Study Area}

West Branch Canal Creek is a tidally influenced freshwater wetland, with a tidal range of approximately $2 \mathrm{ft}$. At low tide, West Branch Canal Creek is about $15 \mathrm{ft}$ wide where the northern transect crosses it. At high tide, the creek can be wider than $350 \mathrm{ft}$. The tides influence ground-water levels in most of the wells along the creek and in the wetland, and there are also seasonal changes in ground-water levels. Seasonal fluctuations in recharge result in fluctuating ground-water levels, particularly in the upland areas. For this preliminary model, both the influence of the tides and the influence of seasonal changes in recharge are ignored. As a simplifying assumption, the ground-water levels in this model are assumed to be at steady state. The simulations of ground-water flow are therefore calculated using the equations for steady-state ground-water flow.

BIOMOC simulates two-dimensional ground-water flow. Using BIOMOC to simulate the northern transect requires the assumption that the direction of ground-water flow is parallel to the transect.

\section{Contaminant Distribution}

Comprehensive sampling of the wells in the wetland for CVOCs was performed only once between June and October 1995 (Olsen and others, 1997). From this sample data and the interpretations by Lorah and others (1997), it is not possible to obtain information needed for determining time scales necessary for simulation. Historical records from the area do not show when the contamination reached the ground water. The best 
available time-series data for determining the behavior of the contaminants in the vicinity of the northern transect come from monitoring well CC27A.

Monitoring well CC27A had the highest measured concentrations of CVOCs at the study site (Lorah and others, 1997). Concentrations of CVOCs in that well have been measured several times since its installation in the mid-1980's. Well CC27A (fig. 3), though not along the transect, is located approximately $100 \mathrm{ft}$ from the northern transect and has a 5- $\mathrm{ft}$ screened interval. Concentrations of PCA in this well have been as high as 5,800 micrograms per liter $(\mu \mathrm{g} / \mathrm{L})$ and as low as $2,300 \mu \mathrm{g} / \mathrm{L}$. Although the measured concentrations of PCA have been variable for the past decade, the data show no distinct trend over time (fig. 6). The average of six separate measurements is approximately $4,000 \mu \mathrm{g} / \mathrm{L} \mathrm{PCA}$ (Lorah and Vroblesky, 1989, table 10; Lorah and Clark, 1996, appendix B; Olsen and others, 1997, table 8A; and Jacobs Engineering Group Inc., 1995, volatile organics table).

The concentration of PCA in well CC27A is assumed to be representative of the concentration trend for the plume of contaminated ground water along West Branch Canal Creek. For these preliminary simulations, the lack of a definitive trend in the concentration data over approximately 10 years is used as justification for the use of steady-state solute-transport simulations to represent the site.

Because well CC27A is not a part of the northern transect, measured concentrations at that well were used only as a guide in selecting a concentration boundary condition for the simulations. A constant-concentration boundary condition of $5,000 \mu \mathrm{g} / \mathrm{L}$ PCA was selected for the calibrated simulation. The source is modeled as a constant-concentration source along $6.5 \mathrm{ft}$ of the right-hand boundary of the modeling domain. The concentration and the length of the concentration boundary condition were adjusted during calibration to arrive at these values. Source size and concentration were not included in the sensitivity analysis, so the model sensitivity to these parameters has not been identified.

Sorption in the wetland sediments affects transient transport simulations through the retardation coefficient. In steady-state simulations, sorption is not an important factor. Sorption in the wetland sediments slows down the solutes, thereby increasing their residence time. Measured sorption coefficients for PCA, isomers of DCE, and VC in wetland sediments are not used in this model. BIOMOC does not allow for distributed sorption coefficients. The simplifying assumption made for these simulations is that the entire simulation domain has a retardation coefficient of 1 . This results in faster transport for the CVOCs in the wetland sediments in the simulations than in reality. The wetland sediments are also the site of the most effective biodegradation occurring at West Branch Canal Creek. If transient simulations were necessary, this would be an important simplifying assumption. Sorption, however, is not an important factor in steady-state solute-transport simulations not involving radioactive decay; in these cases, the retardation coefficient is eliminated from the transport equation (Essaid and Bekins, 1997, equation 3). 


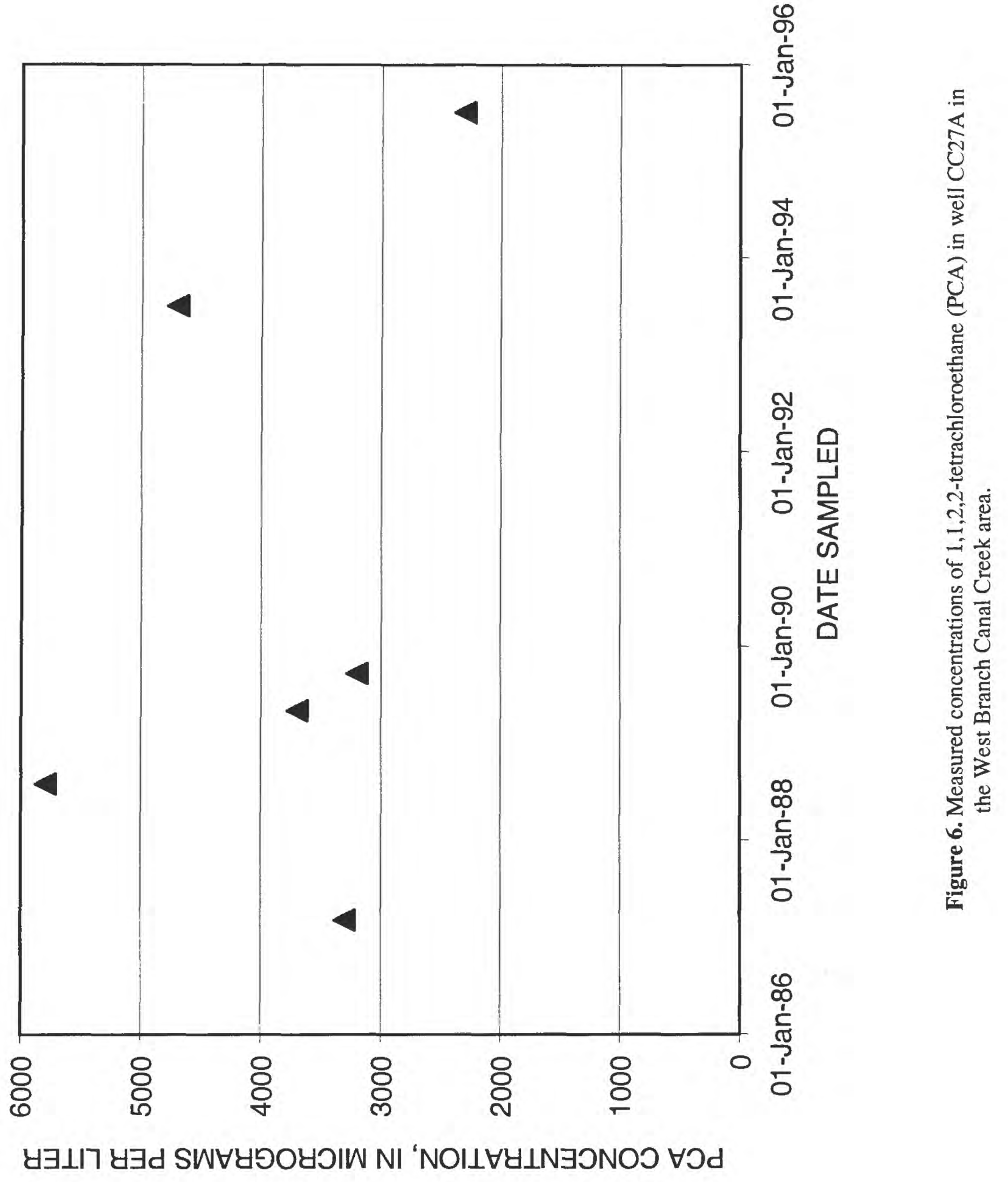




\section{Microbiology}

The spatial distribution of microbiological communities has been analyzed at West Branch Canal Creek using redox parameters as a surrogate (Lorah and others, 1997, fig. 28). This distribution is important because contaminant biodegradation rates are significantly influenced by the dominant type of microbiological community. Because data describing the biodegradation rates for each type of microbiological community have not yet been gathered, a simplified set of communities is simulated. The microbiological communities in this modeling effort are divided into two categories: aerobic and anaerobic. It is assumed that most of the anaerobic zones behave as if they were methanogenic, but in general, this is an inaccurate assumption and should be addressed in more detail in future modeling work. Because rates of biodegradation in the iron-reducing zones have not been identified and are expected to be much lower than the rates found in methanogenic zones, some zones known to have iron-reducing conditions have been simulated as aerobic. The redox zones used in this study are shown in figure 7. The actual redox zones are shown in Lorah and others (1997, fig. 28). A further simplifying assumption is that the microbiological communities and their activities can be simulated as constant in time and space. This assumption cannot be verified on the basis of available data.

\section{Biodegradation Reaction Pathways}

The primary contaminants of concern at West Branch Canal Creek are PCA and TCE, which are biodegraded toward innocuous compounds under anaerobic conditions in several steps. Although the reaction pathways are still the subject of active research, a current understanding of the degradation pathways is shown in figure 8. For PCA degradation, there are three possible reaction pathways and eight different chlorinated daughter products on the pathway to complete degradation. Instead of modeling all of the reaction pathways and all of the daughter products, a simplifying assumption is made that the complete set of reactions can be illustrated by three reaction rates and three compounds. The simplification is to group all of the CVOCs with two or three chlorines and assume that they will all be transformed to $\mathrm{VC}$. In reality, this is not the case because this assumption ignores the pathway from 112TCA to 12DCA. The assumption also requires the 12DCA pathway to degrade at the same overall rate as the VC pathway. The simplified reaction pathway is shown in figure 9.

The approach is to fit the simplified framework to methanogenic microcosm data (Lorah and others, 1997, experiment E4, p. 71) to obtain biodegradation rates. Sequential first-order degradation equations are fit to data from the microcosm experiment using a least-squares search algorithm. The fit and resulting parameters are shown in figure 10. The first-order degradation rates used in the model are 0.21 per day, 0.19 per day, and 0.11 per day, to represent the biodegradation of PCA, the biodegradation of daughter products with two or three chlorines (DAU), and the biodegradation of VC, respectively. The leastsquares search algorithm used in this analysis resulted in a slightly lower biodegradation rate for PCA ( 0.21 per day) than the rate of 0.25 per day calculated by Lorah and others (1997, table 5). 


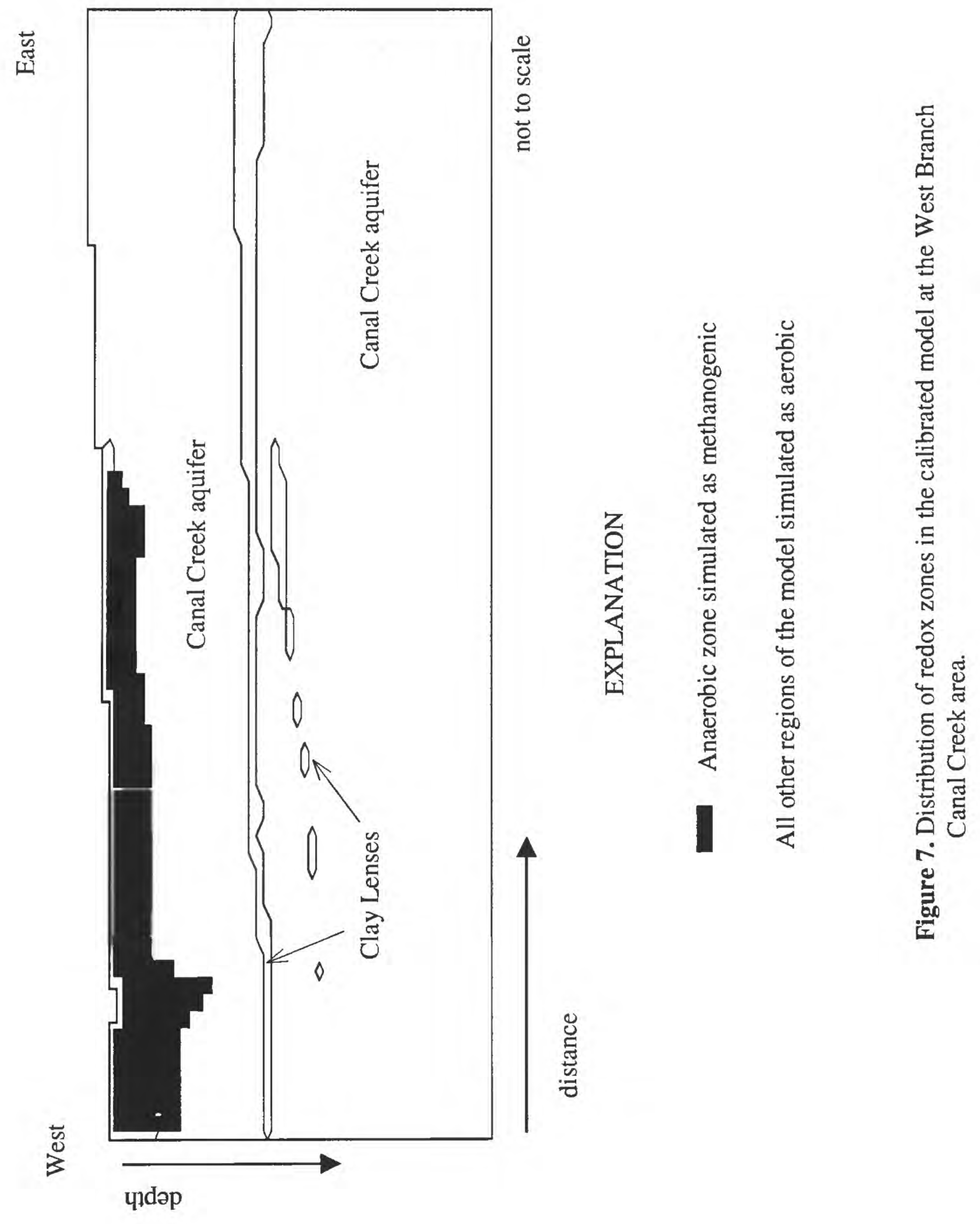



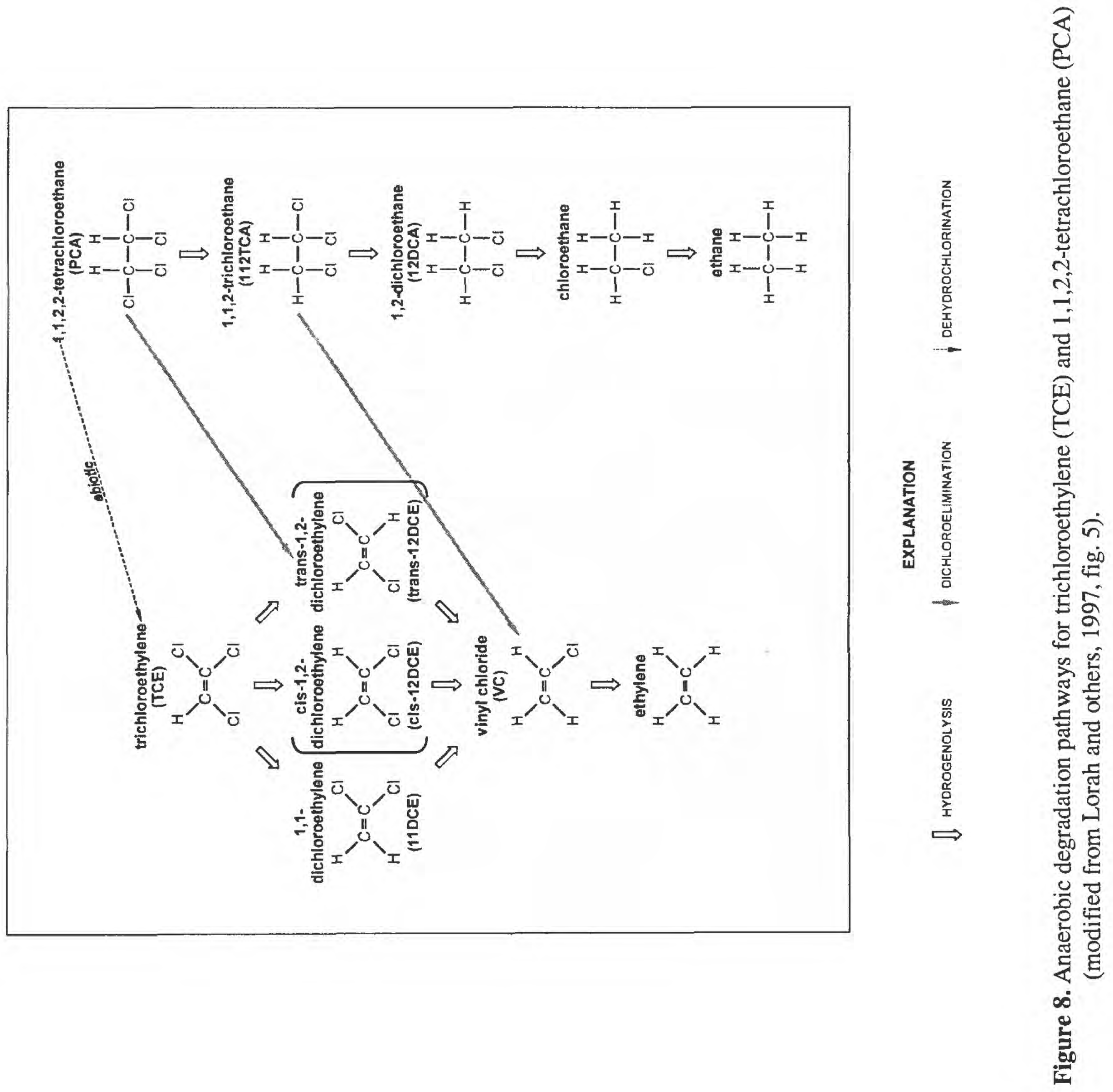


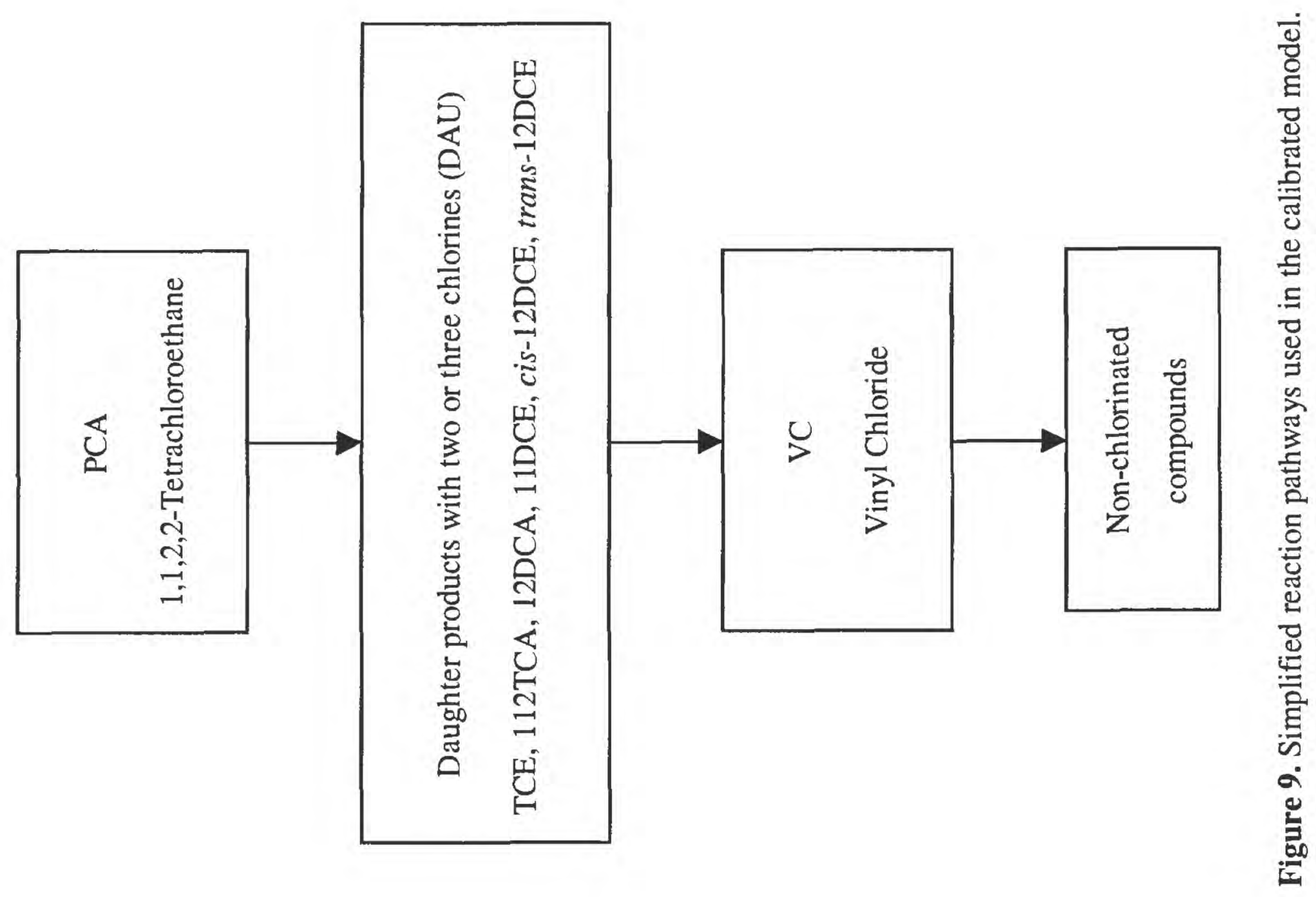



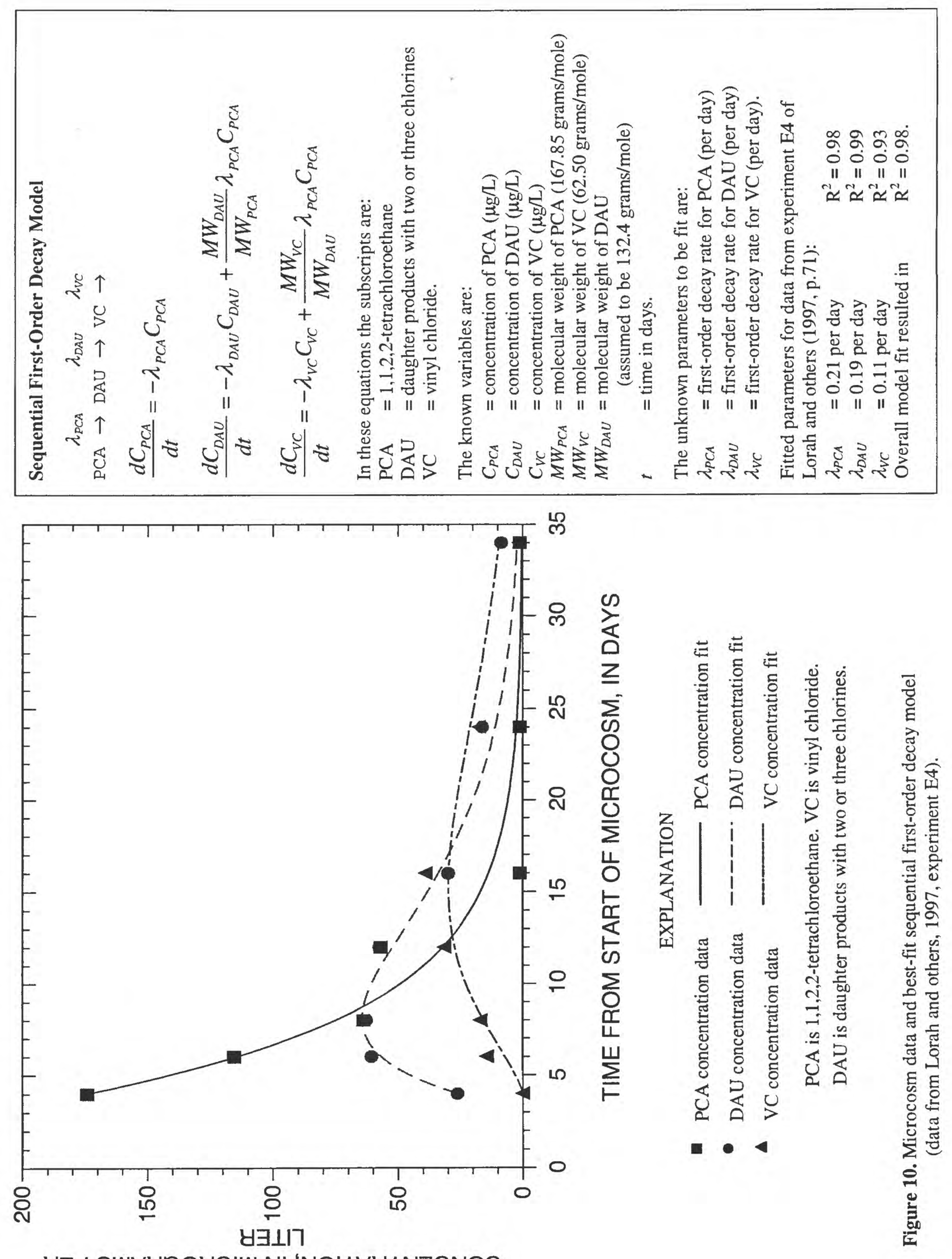

yヨd SW 
It was assumed that no biodegradation takes place in the aerobic sediments of the Canal Creek aquifer; that is, the reaction rates for PCA, DAU, and VC are all assumed to be equal to zero. This simplifying assumption is a conservative estimate of the reaction rates in the aerobic zone.

\section{MODEL CALIBRATION, SENSITIVITY ANALYSIS, AND RESULTS}

The model is manually calibrated to historical ground-water levels and to historical PCA concentrations. No distinction is made between the calibrations; parameters are selected on the basis of both data sets. The model is not calibrated for concentrations of chlorinated daughter products. The low-tide ground-water-level data from May 2, 1996 along the C-C'transect (Olsen and others, 1997, table 6) and PCA concentrations measured between June and October 1995 (Olsen and others, 1997, table 11) are used as the calibration data set.

In the simulations, a large percentage of the PCA is removed by biodegradation in the wetland sediments, but these results must be interpreted in light of the simplifying assumptions made. The measured data and simulated results are listed in table 1. Results of a model sensitivity analysis indicate that ground-water flow is most sensitive to boundary condition values and transport of CVOCs is most sensitive to values of dispersion coefficients and flow velocities. 
TABLE 1. Model-calibration data for two-dimensional ground-water-flow and solute-transport model at West Branch Canal Creek, Aberdeen Proving Ground, Maryland [ft, feet; <, less than; $\mu \mathrm{g} / \mathrm{L}$, micrograms per liter; --, no data]

\begin{tabular}{|c|c|c|c|c|}
\hline \multirow[b]{2}{*}{ Well } & \multicolumn{2}{|c|}{ Hydraulic head, in $\mathrm{ft}$} & \multicolumn{2}{|c|}{ PCA concentration, in $\mu \mathrm{g} / \mathrm{L}$} \\
\hline & Measured & Simulated & Measured & Simulated \\
\hline$\overline{\text { WB37A }}$ & 0.92 & 1.80 & $<0.2$ & $<0.001$ \\
\hline WB37B & 1.36 & 2.34 & $<0.2$ & $<0.001$ \\
\hline WB37C & 2.45 & 3.53 & 26. & $<0.001$ \\
\hline WB36A & 0.46 & 2.03 & $<0.2$ & $<0.001$ \\
\hline WB36B & 1.43 & 2.56 & 1.2 & $<0.001$ \\
\hline WB36C & -- & -- & 95. & 0.02 \\
\hline WB36D & 2.57 & 3.78 & 47. & 0.01 \\
\hline WB36E & 4.16 & 3.98 & 8.4 & 0.01 \\
\hline WB36F & -- & -- & 3.6 & $<0.001$ \\
\hline WB36G & 4.76 & 4.45 & 5.9 & $<0.001$ \\
\hline WB35A & 1.06 & 2.10 & 1.5 & $<0.001$ \\
\hline WB35B & 1.33 & 2.63 & 300 & $<0.001$ \\
\hline WB35C & 2.43 & 3.49 & 300 & 0.58 \\
\hline WB35D & 2.62 & 3.80 & 120 & 0.31 \\
\hline WB35E & - & -- & 130 & 0.15 \\
\hline WB35F & 4.50 & 4.35 & 3.8 & 0.04 \\
\hline WB34A & 1.58 & 1.78 & 0.31 & $<0.001$ \\
\hline WB34B & 2.28 & 3.51 & 380 & 30. \\
\hline WB34C & 2.98 & 3.92 & 120 & 10. \\
\hline WB34E & - & -- & 4.4 & 3.0 \\
\hline WB33A & 3.10 & 3.84 & 2000 & 640 \\
\hline WB33B & 3.40 & 4.05 & 150 & 560 \\
\hline WB33F & 5.00 & 4.71 & 6.2 & 0.19 \\
\hline
\end{tabular}

\section{Calibration of the Model}

The low-tide ground-water-level data from May 2, 1996 along the C-C'transect (Olsen and others, 1997, table 6) is used as the calibration data set. This data set was selected because it has been presented and interpreted in a previous report (Lorah and others, 1997, fig. 11), and because it represents a relatively complete data set for the wells along the C-C'transect. Selection of the low-tide event as the calibration data set was arbitrary because the influence of the tides results in continuously changing ground-water levels in most of the wells along the transect. The model was calibrated through a trial-anderror approach wherein boundary conditions, hydraulic conductivities, and anisotropy ratio were adjusted until a reasonable match was achieved between the observed and simulated ground-water levels. The calibration resulted in a root-mean-squared error of 0.95 $\mathrm{ft}$ for the 19 observation points used. 
To calibrate the model to measured ground-water levels, hydraulic-conductivity values were adjusted from initial estimates within the range of measured values. Calibration was obtained with hydraulic conductivities in the Canal Creek aquifer of $2 \mathrm{ft} / \mathrm{d}$ for the sand below the clay lenses, and $1 \mathrm{ft} /$ day for the sand above the clay lenses. These values are consistent with measured hydraulic conductivities. The clay lenses were assigned a hydraulic conductivity of $0.3 \mathrm{ft} / \mathrm{d}$. Calibration was obtained with a hydraulic conductivity for the wetland sediments of $0.1 \mathrm{ft} / \mathrm{d}$, which is close to the highest value measured for the wetland sediments. Simulations containing lower values of hydraulic conductivity for the wetland sediments did not match the observed heads. The calibrated model uses an anisotropy ratio (the ratio between vertical and horizontal hydraulic conductivity) of 0.05 . This results in a vertical hydraulic conductivity for the wetland sediments of $0.005 \mathrm{ft} / \mathrm{d}$.

The model is calibrated to the PCA concentrations measured between June and October 1995 (Olsen and others, 1997, table 11), and to the interpretation of those concentrations (Lorah and others, 1997, fig. 22). The model was calibrated through a trial-anderror approach where boundary conditions, transverse and longitudinal dispersivities, hydraulic conductivities, and anisotropy ratio were adjusted until a reasonable match was achieved between the interpreted and simulated concentrations. Additional adjustments were made to minimize the root-mean-squared error between the simulation and the observations. Most of the observation points are located in the vicinity of the creek channel, making it difficult to calibrate to the PCA concentration data independent of the interpretation. The calibration resulted in a root-mean-squared error of $321 \mu \mathrm{g} / \mathrm{L} \mathrm{PCA}$ for 23 observation points. The simulation underestimates the concentration of PCA in the Canal Creek aquifer for most of the observation points. Comparing the simulated concentrations with the interpreted concentrations, however, shows relatively good agreement with the shape and extent of the PCA plume. The simulations underestimate PCA concentrations in the vicinity of the creek channel. Including the dispersive effect of the tides upon the transport of CVOCs would likely improve the calibration in that region of the model domain.

Calibrating the model to PCA concentration data required setting boundary conditions based on the concentrations. The calibrated model contains a constant concentration source along $6.5 \mathrm{ft}$ of the eastern boundary of the domain. The source has a concentration of 5,000 $\mu \mathrm{g} / \mathrm{L}$ PCA. Measured concentrations at well CC27A were used as a guide in selecting a concentration boundary condition for the simulations. The concentration and length of the concentration boundary condition were adjusted during the calibration step of the modeling to arrive at these values.

Solute dispersivity and ground-water-flow velocity were adjusted to calibrate the model to measured PCA concentrations. The calibrated value for longitudinal dispersivity is $0.3 \mathrm{ft}$, and the calibrated value for the dispersivity ratio (longitudinal to transverse) is 1 . Hydraulic conductivity, anisotropy ratio, and porosity values were altered to adjust ground-water-flow velocity. The calibrated value for porosity is 0.38 , and is required by BIOMOC to be uniform over the entire domain. This is a high value for aquifer sediments, but probably a low value for the wetland sediments. Because a uniform value was necessary, and because the porosity had a relatively small impact on the results, little adjustment was made to refine the porosity value used in the simulation. The calibrated values for hydraulic conductivity, anisotropy ratio, and porosity are the same for the calibration to ground-water-level data and PCA concentration data. No distinction is made between these calibrations; parameters were selected on the basis of both data sets. 
Manual methods of calibration are not guaranteed to yield parameter values that match field values, nor are they guaranteed to yield the best of all possible parameter sets. The selection of parameters by manual calibration is simply a "best guess" using experience and the field data as a guide.

\section{Model Sensitivity Analysis}

A sensitivity analysis was performed for the major parameters in the model. The sensitivity of the model is measured by computing the root-mean-squared error in the distribution of simulated ground-water levels and PCA concentrations due to a change in the value of a single parameter. The calibrated simulation is used as the baseline for the sensitivity analysis (it is assigned a root-mean-squared error of zero), and the root-meansquared error is computed so that it includes every grid block in the simulation. The parameters were varied within a plausible range. Results of the sensitivity analysis are plotted in figures 11 and 12 . For many parameters, the model was found to be more sensitive to an increase than to a decrease in the value of that parameter.

The effects of a parameter change on the ground-water-level distribution are shown in figure 11. The model is most sensitive to the magnitude of the constant-head boundary condition along the eastern boundary and eastern part of the lower boundary. The model is also found to be sensitive to the hydraulic conductivity of the wetland sediments.

Given the sensitivity of the simulation results to changes in the value of the boundary conditions, an additional boundary condition was evaluated. The boundary along the eastern part of the lower boundary was changed from a constant-head boundary of $5 \mathrm{ft}$ to a no-flow boundary. The change resulted in only a 7-percent difference in the amount of water leaving the wetland at the upper boundary, a root-mean-squared error of $0.09 \mathrm{ft}$ for the distribution of ground-water levels, and a root-mean-squared error of $68 \mu \mathrm{g} / \mathrm{L}$ for the PCA concentration distribution. A constant-head boundary was selected for the calibrated simulation because it more accurately matched the observed water levels in the vicinity of the boundary.

The effects of a parameter change on the PCA concentration distribution are shown in figure 12. The sensitivity analysis shows that the contaminant transport is most sensitive to the dispersion coefficients. Changes to the hydraulic conductivity of the sand and the wetland sediments result in similar sensitivities for adjustments to lower values. Changes to the hydraulic conductivities in these simulations affect the ground-water velocity field. Although velocity is not a separate parameter in this analysis, the sensitivity of the simulation to changes in hydraulic conductivity indicates sensitivity to changes in ground-water velocity. 


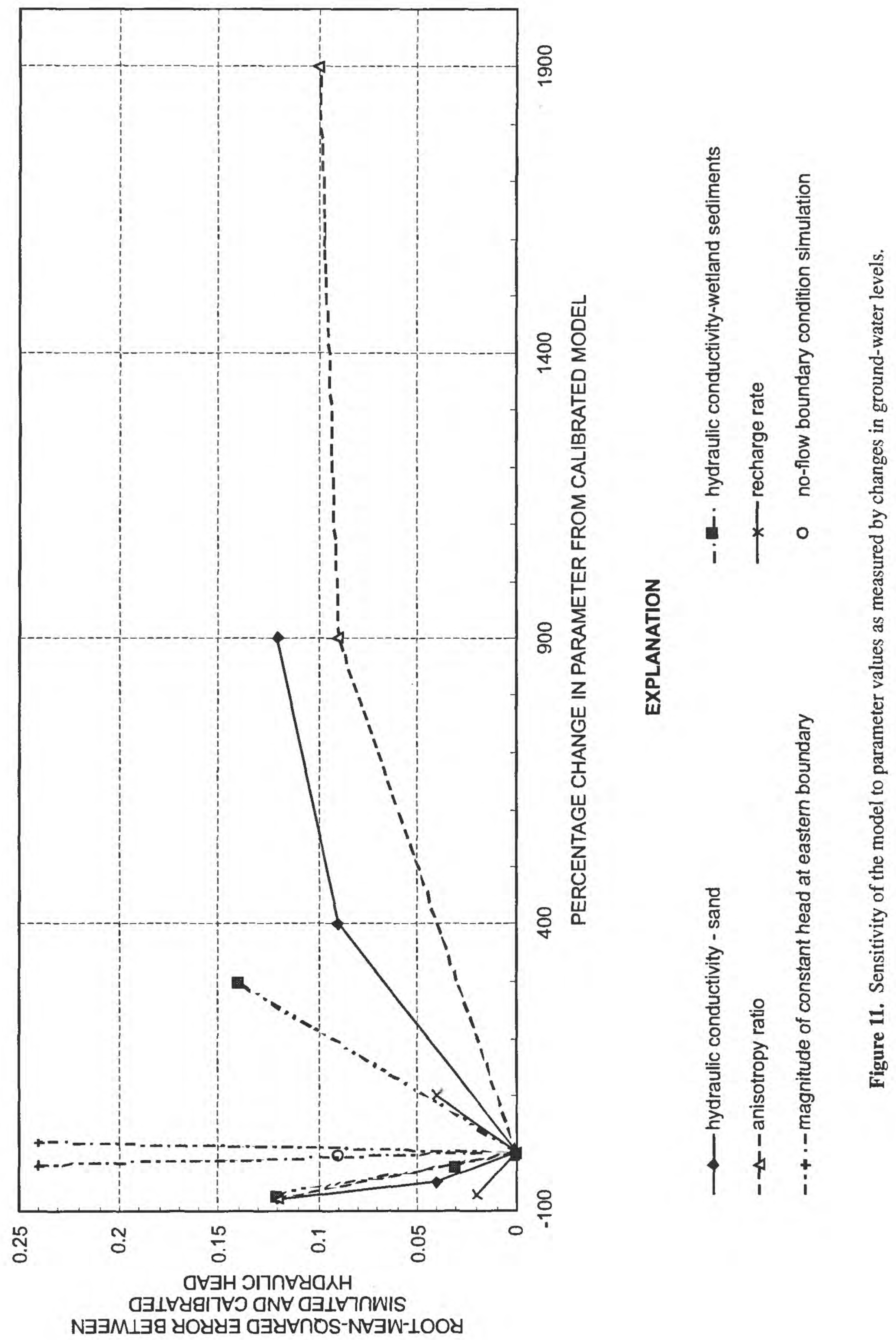




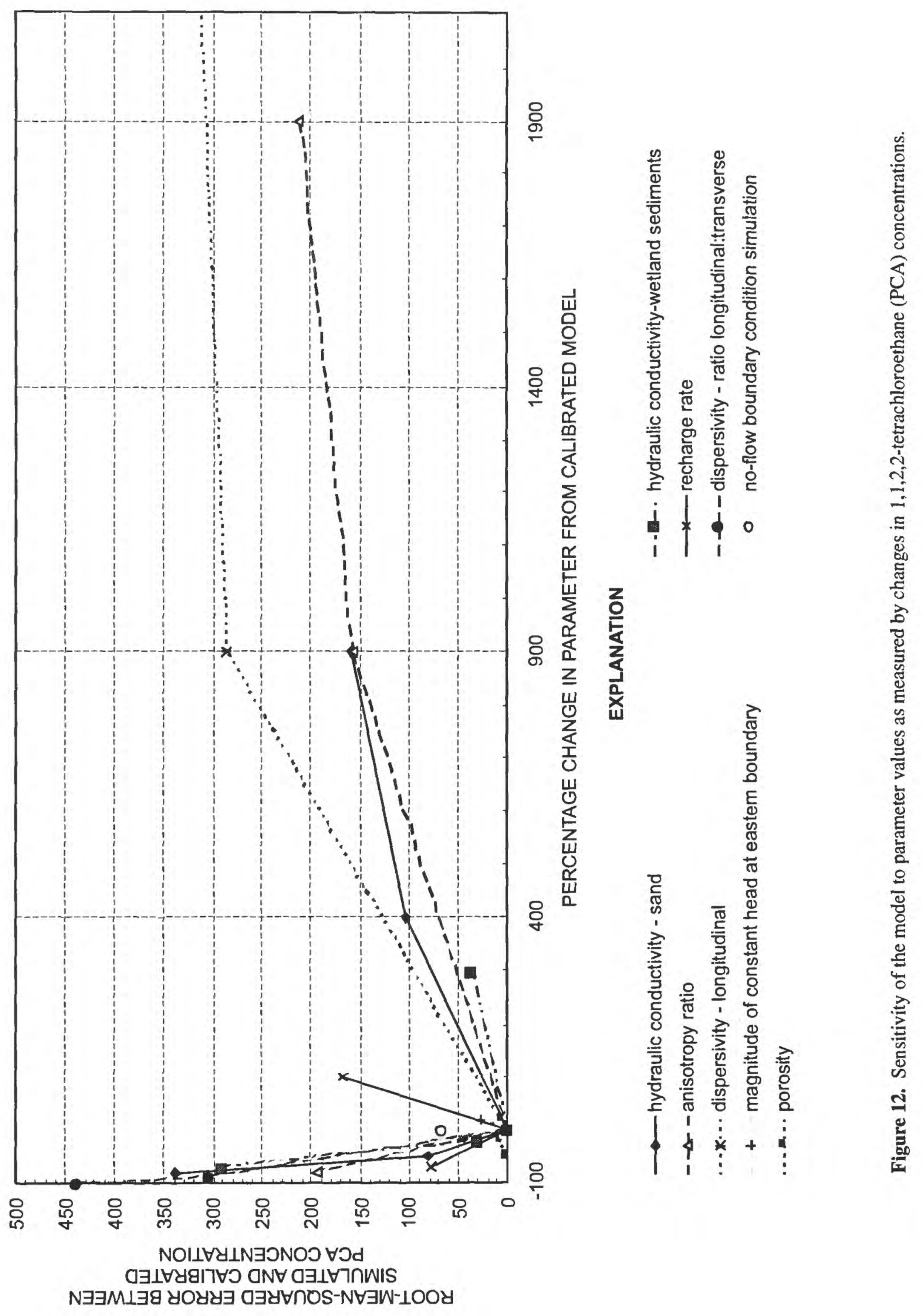




\section{Simulation Results}

The model simulates biodegradation of CVOCs from the parent compound PCA through the degradation of VC. On the basis of the calibrated simulation, 99.89 percent of the PCA entering the domain boundaries is biodegraded prior to leaving the model boundary. The remaining 0.11 percent is released to the surface of the wetland, where it would be either volatilized or diluted by the tides. The average simulated concentration of PCA reaching the wetland surface is less than $0.01 \mu \mathrm{g} / \mathrm{L}$. The maximum simulated PCA concentration reaching the wetland surface is $10 \mu \mathrm{g} / \mathrm{L}$. The maximum simulated concentration of daughter products (with two or three chlorines) reaching the wetland surface is $0.01 \mu \mathrm{g} /$ $\mathrm{L}$, and the maximum simulated concentration of $\mathrm{VC}$ reaching the wetland surface is 10 $\mu \mathrm{g} / \mathrm{L}$. Once the CVOCs reach the wetland surface, volatilization and dispersion caused by the tides will further reduce their aqueous concentrations. The concentration distribution for PCA, daughter products (with two or three chlorines), and VC for the calibrated model is shown in figure 13.

It is important to consider the effects the simplifying assumptions have on these results. The three major simplifying assumptions that have bearing on these results are as follows: (1) dispersion due to the influence of the tides is not included in the simulations. This assumption is likely to result in simulations that overestimate the concentration of solutes reaching the wetland surface; (2) the ground-water flow and reactive-solute transport at the site can be adequately represented using two-dimensional steady-state simulation. It is assumed that the plume of contaminated ground water has reached steady-state conditions so that sorption of solutes to wetland sediments can be ignored and that ground-water flow is parallel to the northern transect; and (3) a simplified set of reactions rather than the complete set of degradation reactions was simulated. This simplified set of reactions reduces the complexity of the simulations, yet maintains a representation of the entire degradation pathway. Individual daughter product compounds, however, may degrade at rates different from the bulk set of daughter products (with two or three chlorines) simulated here. Different degradation rates would result in different concentrations of CVOCs reaching the wetland surface.

\section{SUMMARY}

West Branch Canal Creek is a tidally influenced freshwater wetland that receives discharge from a sand aquifer beneath the wetland. A plume of chlorinated volatile organic compounds in the aquifer is transported to the wetland sediments where it undergoes biodegradation. Previous U.S. Geological Survey studies described the hydrogeology, geochemistry, and biogeochemistry of this site. This information has been used to simulate the processes of natural attenuation.

The goal of previous U.S. Geological Survey work at the site was to provide a framework for understanding the distribution and movement of the chlorinated volatile organic compounds, and to quantify the extent of natural attenuation. The objectives of this report are to begin to quantify the effect of biodegradation on the fate of the chlorinated volatile organic compounds, and to begin to examine the sensitivity of the system to changes in environmental conditions. 

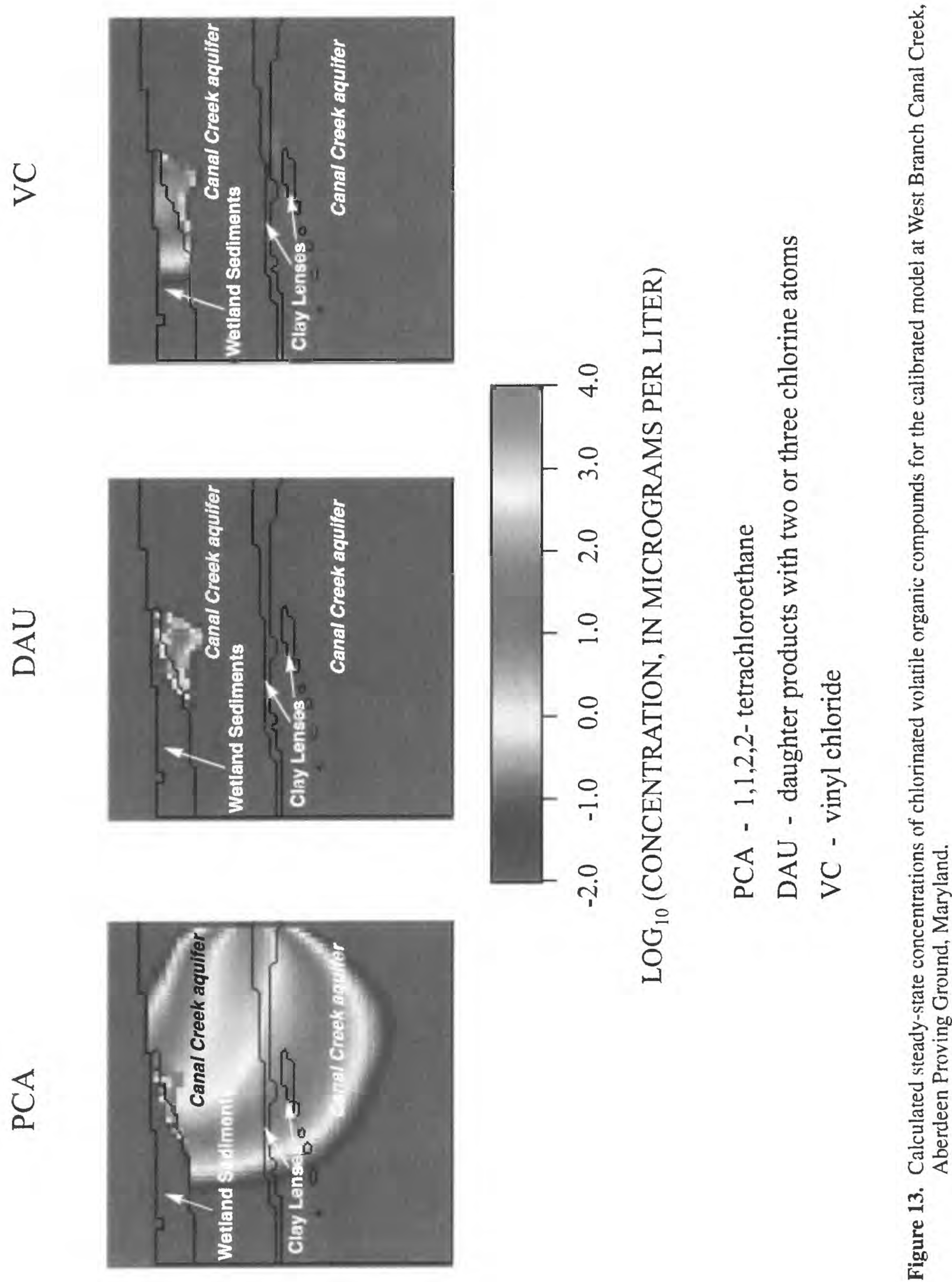
Simulations were constructed based on the hydrologic, geochemical, and biogeochemical framework developed in previous studies. The model domain was chosen to be representative of a two-dimensional cross section perpendicular to and extending about 200 feet southeasterly from the creek. This cross section intersects a contaminant plume of chlorinated volatile organic compounds including trichloroethylene; 1,1,2,2- tetrachloroethane; 1,1,2- trichloroethane; chloroform; carbon tetrachloride; cis-1,2- dichloroethylene; trans-1,2- dichloroethylene; 1,2- dichloroethane; and vinyl chloride. The predominant contaminant of concern is 1,1,2,2- tetrachloroethane because it exists at higher concentrations than the other chlorinated volatile organic compounds measured at the site. The geochemical framework developed in previous studies is greatly simplified for the purposes of these simulations. All anaerobic zones found in the cross section are simulated as methanogenic. Biodegradation rates are obtained for a simplified set of chlorinated volatile organic compounds based on experimental data from a previous investigation. The biodegradation rates are used in a two-dimensional flow, transport, and biodegradation model to simulate the transport and fate of the chlorinated volatile organic compounds. The model is calibrated to water-level data gathered in 1996 and 1,1,2,2-tetrachloroethane concentration data gathered in 1995.

On the basis of the calibrated simulation, 99.89 percent of the 1,1,2,2- tetrachloroethane entering the domain boundaries is biodegraded prior to leaving the model boundary. The remaining 0.11 percent is released to the surface of the wetland, where it would be either volatilized or diluted by the tides. The average simulated concentration of $1,1,2,2$ - tetrachloroethane reaching the wetland surface is less than 0.01 micrograms per liter. The maximum simulated 1,1,2,2- tetrachloroethane concentration reaching the wetland surface is 10 micrograms per liter. The maximum simulated concentration of daughter products (with two or three chlorines) reaching the wetland surface is 0.01 micrograms per liter, and the maximum simulated concentration of vinyl chloride reaching the wetland surface is 10 micrograms per liter. After the chlorinated volatile organic compounds reach the wetland surface, volatilization and dispersion caused by the tides will further reduce their aqueous concentrations.

Simulating the natural attenuation processes required the use of simplifying assumptions regarding the hydrology and transport properties of the materials at the site. The most important simplifying assumptions relevant to the results are as follows: (1) the diurnal and seasonal changes in ground-water levels due to the influence of the tides are not included; (2) the ground-water flow and reactive-solute transport are represented using a two-dimensional steady-state simulation; and (3) a simplified set of biodegradation reactions are employed rather than the whole set of reactions and resultant daughter products. The model is sensitive to dispersivity and velocity, and would benefit from additional data on these parameters. 


\section{REFERENCES CITED}

Essaid, H.I., and Bekins, B.A., 1997, BIOMOC, A multispecies solute-transport model with biodegradation: U.S. Geological Survey Water-Resources Investigations Report 97-4022, 68 p.

Jacobs Engineering Group Inc., 1995, Remedial investigation progress report, Canal Creek study area, Aberdeen Proving Ground - Edgewood area, Maryland: September: Baltimore, Maryland, [variously paged.]

Konikow, L.F., and Bredehoeft, J.D., 1978, Computer model of two-dimensional solute transport and dispersion in ground water: U.S. Geological Survey Techniques of Water-Resources Investigations, book 7, chapter C2, 90 p.

Lorah, M.M., and Vroblesky, D.A., 1989, Inorganic and organic ground-water chemistry in the Canal Creek area of Aberdeen Proving Ground, Maryland: U.S. Geological Survey Water-Resources Investigations Report 89-4022, 97 p.

Lorah, M.M., and Clark, J.S., 1996, Contamination of ground water, surface water, and soil, and evaluation of selected ground-water pumping alternatives in the Canal Creek area of Aberdeen Proving Ground, Maryland: U.S. Geological Survey Open-File Report 95-282, 318 p.

Lorah, M.M., Olsen, L.D., Smith, B.L., Johnson, M.A., and Fleck, W.B., 1997, Natural attenuation of chlorinated volatile organic compounds in a freshwater tidal wetland, Aberdeen Proving Ground, Maryland: U.S. Geological Survey WaterResources Investigations Report 97-4171, 95 p.

Oliveros, J.P., and Vroblesky, D.A., 1989, Hydrogeology of the Canal Creek area, Aberdeen Proving Ground, Maryland: U.S. Geological Survey Water-Resources Investigations Report 89-4021, 50 p.

Olsen, L.D., Lorah, M.M., Marchand, E.H., Smith, B.L., and Johnson, M.A., 1997, Hydrogeologic, water-quality, and sediment-quality data for a freshwater tidal wetland, West Branch Canal Creek, Aberdeen Proving Ground, Maryland, 1992-1996: U.S. Geological Survey Open-File Report 97-560, 267 p. 